\title{
Az angol nyelvű walesi irodalom fogalmáról és történetéről
}

2004-ben a University of Wales Press impozáns és azóta is sikeres vállalkozásban kezdett: Writing Wales in English (Az angolul íródó Wales) címmel sorozatot indított, melynek első kötete Stephen Knight írása, az A Hundred Years of Fiction (Százévnyi próza). Mindkét cím önmagában is állásfoglalás: a sorozaté finom tapintattal kerüli el a walesi irodalom fogalmát azzal, hogy nem nemzetiségi, hanem nyelvi és tematikus alapon határolja körül tárgyát; a köteté pedig a 19. és 20. század fordulójára datálja annak a modern irodalmi jelenségnek a születését, amely nyelvileg ugyan az angol kultúrkörhöz tartozik, ám különleges walesi kötődéssel bír. De miért ilyen bonyolult a „walesi irodalom”-ról beszélni?

A fogalmi bizonytalanság hátterében a 13. századi angol hódításban és az azóta is tartó walesi-angol szembenállásban gyökerező nyelvi és nemzetiségi kérdések állnak - olyan politikai és kulturális ellentétek, amelyek bőséges alapot szolgáltatnak az ország irodalmának gyarmati kontextusban történő olvasásához. ${ }^{1}$ Egyszerü lenne M. Wynn Thomas szavaival azt mondani, hogy Walesnek két kultúrája és irodalma van, ${ }^{2}$ egy walesi nyelven és egy angolul íródó. Ezért nevezhette 1968-ban Glyn Jones azóta szállóigévé vált metaforával Walest „kétnyelvü sárkány”-nak. ${ }^{3}$ A nyelvi hovatartozás és a nemzeti identitás azonosságát sugalló „walesi-angol” kétosztatúság azonban több szempontból is problematikus. Először is, mint Knight rávilágít, paradoxont rejt a nemzeti nyelvü irodalomnak a Welsh, azaz walesi jelzővel történő megjelölése, hiszen a germán eredetű szó eredetileg ,idegen”-t vagy „külföldi”-t jelent. İgy Knight sok más szerzővel együtt a Cymraeg jelző mellett teszi le a voksát, ${ }^{4}$ amely a Cymru szóból, az önálló hercegségekből (Gwynedd, Powys, Dyfed, Gwent stb.) álló országnak körülbelül a 7. századtól használt kelta nevéből származik. ${ }^{5}$ Másrészt, az angolul

\footnotetext{
${ }^{1}$ Vö. Kristi Bohata, Postcolonialism Revisited, Cardiff, University of Wales Press, 2004, 3-4. Lásd még Stephen Knight, Welsh Fiction in English as Postcolonial Literature = Postcolonial Wales, eds. Jane AAron, Chris Williams, Cardiff, University of Wales Press, 2005, 159-176.

${ }^{2}$ M. Wynn Thomas, Corresponding Cultures: The Two Literatures of Wales, Cardiff, University of Wales Press, 1999, 1-6.

${ }^{3}$ Glyn Jones, The Dragon Has Two Tongues (1968), idézi Thomas, i. m., 103.

${ }^{4}$ Stephen Knight, A Hundred Years of Fiction, Cardiff, University of Wales Press, 2004, XV.

${ }^{5}$ Mivel a Cymraeg irodalom kívül esik a jelen írás horizontján, ezért az ide tartozó szerzőkről röviden csak annyit említek, hogy - némi egyszerüsítéssel - két csoportra oszthatóak. Vannak, akik mindkét nyelven publikálnak, saját fordításukban vagy fordítók közremüködésével, mint például John Ellis Williams (1924-2008), Robin Llywelyn (1958-), vagy a fiatalabb nemzedék tagjai közül Fflur Dafydd (1978-).
} 
publikáló, de attól még walesi származású és/vagy nemzeti érzületű, walesi témákat tárgyaló írók megnevezésében valamilyen módon tükröződnie illik mind a „Cymraeg” szerzőktől való nyelvi, mind az angol íróktól való nemzeti identitásbeli elhatárolódásnak. A gyakran használt Anglo-Welsh, azaz walesi-angol megjelölés azonban a gyarmatosítás termékeként kialakult kettős nemzeti kötődést sugall, ami e szerzők többsége számára elfogadhatatlan. ${ }^{6}$ Innen a komplex nyelvi-tematikus elhatárolás igénye, s Knight szóhasználatában az „,angol nyelvü walesi irodalom” („Welsh writing in English") kissé nehézkes fogalma. ${ }^{7}$ A leegyszerüsítő megnevezések ellen szólnak azok az angol nyelven írt walesi témájú müvek is, amelyeknek a szerzője nemzetiségét tekintve is angol. Vajon ezek a művek a walesi irodalom részei-e? Kézenfekvő példa John Cowper Powys (1872-1963), aki - bár csak távoli walesi ősökkel rendelkezett - 1935-től haláláig Walesben élt, walesinek vallotta magát, $s$ két monumentális történelmi regényben, az Owen Glendowerben $(1940)^{8}$ és a Poriusban $(1951)^{9}$ dolgozott fel walesi témát. Jeremy Hooker számára ez már elegendő ahhoz, hogy fejezetet szenteljen az írónak az angol nyelvű walesi irodalmat tárgyaló monográfíáában. ${ }^{10} \mathrm{Nem}$ mondható el viszont semmi hasonló Kingsley Amisről (1922-1995), bár tizenhárom évig volt a Swansea Egyetem oktatója (1949-1961), és éppen Booker Prize-nyertes The Old Devils (Vén ördögök, 1986 $)^{11}$ című regénye játszódik Walesben, walesi főszereplőkkel. Mindezek tudatában jelen írás a Knight körképében tükröződő konszenzust követi az angol nyelvű walesi irodalom fogalmának használatakor.

Mivel ezen irodalom a fentiek szerint laza tematikus egységet alkot, érdemes felidézni a gyarmatosítás kontextusához kötődő és e tematikát körülrajzoló eredettörténetét. Bár e történet 1282-ben kezdődik, amikor I. (Nyakigláb) Edward meghódította a ma Walesként ismert kelta területeket, az angol nyelvü walesi irodalmat közvetlenül életre hívó kulturális közeg kialakulásának gyökerei az ipari forradalmak korában keresendőek. A 18. századtól ugyanis a szénbányászat (Aberdare, Rhondda) és a vaskohászat (Merthyr, Dowlais, Penydarren) fellendülésével az ország kettészakadt az iparosodott Dél-Walesre, valamint a továbbra is vidékies, mezőgazdasági területek-

És vannak, akik egyáltalán nem hajlandóak angolul is megjelentetni műveiket. Így például az 1920-30-as évek walesi politikai életében is markáns szerepet játszó, irodalmi Nobel-díjra jelölt (1970) Saunders Lewis (1893-1985) ellenezte az angol nyelvü walesi irodalom koncepcióját, mondván, hogy a fordítás mindent eltüntet, ami a walesi irodalmat walesivé teszi. Életében egyetlen műve sem jelent meg angolul. Olyan politikai állásfoglalás ez, amely gyakorlatilag a mintegy félmilliónyi kétnyelvủ walesire korlátozza az adott író olvasóközönségét. Vö. BoHATA, i. m., 115.

${ }^{6}$ Vö. Bohata, i. m., 105. Lásd még A New Companion to the Literature of Wales, ed. Meic Stephens, Cardiff, University of Wales Press, 1998, 14-15.

${ }^{7}$ KNIGHT, A Hundred Years, i. m., XV.

${ }^{8}$ John Cowper Powys, Owen Glendower (1940), London, John Lane The Bodley Head, 1941.

${ }^{9}$ John Cowper Powys, Porius: A Romance of the Dark Ages (1951), Hamilton, Colgate University Press, 1994.

${ }^{10}$ Jeremy Hooker, Imagining Wales: A View of Modern Welsh Writing in English, Cardiff, University of Wales Press, 2001, 91-110.

${ }^{11}$ Kingsley Amis, The Old Devils, Harmondsworth, Penguin, 1987. 
ből álló szegényebb Észak-Walesre. Az ipari fellendülés egyre több angol (és ír) betelepülőt vonzott a déli területekre, ami szinte egyszerre vezetett a kulturális konfliktus kiéleződéséhez, és a modern walesi függetlenségi mozgalom megszületéséhez. Az autentikus walesi kultúra elfojtásának szimbolikus alapdokumentuma az az 1847-ben publikált bizottsági jelentés, amelyre egyszerüen csak Blue Books-ként (Kék könyvek) utal a walesi nemzeti emlékezet. A jelentés egyrészt felfedte az akkor kiszélesedő közoktatásban jelenlévő nyelvi ellentéteket: a még túlnyomóan csak walesit beszélő gyerekeket föként angol, csak angolul beszélő, angol tankönyveket használó tanárok tanították. Másrészt egy zseniális gyarmatosító gesztussal rögtön a walesi nyelv használatát jelölte meg az ország kulturális elmaradottságának és erkölcsi fertőjének gyökérokaként, igazolandó az ezt követö rendkívül agresszívan angolosító nyelv- és kultúrpolitikát. ${ }^{12} \mathrm{~A}$ jelentés közvetlen következményeként az oktatás kötelező nyelvévé a 20. század második feléig az angol vált Walesben. Az eredmény a 19. század végére látványos lett: kialakult a mai helyzet, azaz az országban szinte mindenki beszél angolul és az angol gyakorlatilag a fó nyelv, noha Wales 1998 óta hivatalosan is kétnyelvü és a lakosság jelentős százaléka - a kevésbé iparosodott északon és nyugaton jellemzően nagyobb hányad - beszéli a walesit. Mindemellett az 1960-as évekig Walesben nem voltak angol nyelvü kiadók, azaz az angol nyelvü szerzők általában Angliában voltak kénytelenek megjelentetni müveiket, és így írásaik gyakran váltak „burkolt cenzúra” áldozatává. ${ }^{13}$

Tehát az iparosítás, az ezzel járó népességmozgások, illetve a brit birodalmi politika erőfeszítései a 19. és 20. század fordulójára megalapozták az angol nyelvű walesi irodalom egy fontos objektív feltételét: egy viszonylag széles körü angol nyelvü, a walesi témák iránt érdeklődő olvasótábor létrejöttét Walesben. Ez utóbbit az írországihoz hasonló folyamat garantálta: ahogy a nemzeti identitás meghatározásában az erőszakos nyelvpolitika következtében a walesi nyelv viszonylag háttérbe szorult, a politikával egyre inkább összefonódó vallás, illetve a mindkettő céljai számára remek terepet biztosító irodalom kezdte átvenni a szerepét. A vallás az angol kulturális befolyás elleni harc kitüntetett színtere volt a 18. század végén lezajlott metodista újjáéledés kezdetétől, aminek nyomán a nonkonformista felekezetek megdöbbentő népszerűsége, vélemény- és viselkedésformáló szerepe, és az Anglikán Egyház elleni fellépése volt megfigyelhető. ${ }^{14} \mathrm{~A}$ vándorprédikátorok, vallási vezetők politikai szerepvállalása mellett a politikatörténet kulcsfontosságú pillanata mégis csak a Plaid Cymru, a Walesi Párt létrejötte volt 1925-ben. A déli iparosítást követően társadalmi szerkezetéből adódóan alapvetően munkáspárti szavazótáború Walesben ma is markánsan jelen lévő szervezet az Egyesült Királyságból való kiválásért kampányolt, s bár az 1997-es népszavazáson a walesiek jó időre elutasították ezt a lehetőséget, a

\footnotetext{
12 Bohata, i. m., 9-10, 21.

${ }^{13}$ Uo., $12-13$.

${ }^{14} \mathrm{M}$. Wynn Thomas, In the Shadow of the Pulpit: Literature and Nonconformist Wales, Cardiff, University of Wales Press, 2010, 44-76.
} 
lakosság jelentős része ma is elszakadáspárti. A század közepétől a walesi-angol politikai konfliktus újbóli kiéleződésében jelentős szerepet játszott a kohászatnak és a bányászatnak a hatvanas években induló, majd a nyolcvanas évek általános gazdasági válságához kapcsolódóan tragikus méreteket öltő hanyatlása. Wales és Anglia viszonyának politikai rendezését az ezredfordulón - többek között a Walesi Nemzetgyülés létrehozását - viharos, gyakran Észak-Írországot idéző bombamerényletektől sem mentes évtized elözte meg.

Stephen Knight irodalomtörténeti áttekintője nyomán elmondható, hogy az angol-walesi ellentét, a vallási érzülettől áthatott észak-walesi faluközösség (gwerin) ábrázolása, illetve az iparosodott Dél-Wales munkásrétegeinek megnyomorítása szolgáltatták a megszületőben lévő angol nyelvü walesi irodalom legfontosabb témáit. A nyilvánvalóan a kritikai realista megközelítést felértékelő Knight e tematikai egységekből, illetve az ábrázolás hangvételéből kiindulva az angol nyelvü walesi próza három, egymást részben átfedő hullámát különíti el. Az első periódust, amely a 19. század utolsó évtizedeit foglalja magában és Caradoc Evans (1878-1945) korszakalkotó műveinek megjelenésével zárul az 1910-es években, a „románc” időszakának tekinti. Knight véleménye szerint e korszak írásainak közös jellemzője a Wales iránti romantikus attitüd: az urbánus civilizációtól megfáradt, kiábrándult utazó számára idilli, egzotikus, ártatlan álomvilág az ország. Jellegzetesen hazájukból ide „menekülö" angol, vagy Angliában szocializálódott walesi származású írók, illetve még inkább írónők határozzák meg a korszakot. Ilyenek Anne Adaliza Evans (1836-1908), aki az Allen Raine ${ }^{15}$ írói álnevet használta; Hilda Vaughan (1892-1985); ${ }^{16}$ az angol Peggy Whistler (1909-1958), aki Margiad Evans ${ }^{17}$ néven vált ismertté; vagy az iparosodott Dél-Walest „románcosan” megjeleníto Joseph Keating (1871-1934) ${ }^{18}$ Knight szerint ezen attitüdből és irodalomból nő ki ellenpontként az angol nyelvü walesi irodalom első magas szintü művelöjének, atyjának tekintett Caradoc Evans My People (Az én népem, 1915) címü kötete. ${ }^{19} \mathrm{~A}$ keserüen szatirikus, helyenként szarkasztikus elbeszélésfüzér a vidéki Észak-Wales vallási megszállottságát, álszent nonkonformizmusát

\footnotetext{
${ }^{15}$ Első regénye az A Welsh Singer (Walesi énekes, 1897), amelyet majd tucatnyi követett, köztük a Garthowen (1900), az A Welsh Witch (Walesi boszorkány, 1902), az On the Wings of the Wind (Szelek szárnyán, 1903), majd a sokszor Caradoc Evanshoz hasonlított Queen of the Rushes (A sás királynője, 1906). A New Companion, i. m., 611-612.

${ }^{16}$ A kritika a The Invader (A betolakodó, 1928) és a Her Father's House (A lány apjának háza, 1930) címü regényeit tartja leginkább walesi alkotásainak, míg legnagyobb sikerét a The Soldier and the Gentlewoman (A katona és az úrinő, 1932) cíművel aratta. Uo., 755.

${ }^{17}$ Négy regénye közül legnagyobb kritikai figyelmet az első, a későbbiekben tárgyalandó Country Dance (Falusi táncmulatság, 1932) kapott.

${ }^{18}$ Kritikai elismeréssel leginkább a szerző ábrázolásmódjáról sokat elmondó Maurice: the Romance of a Welsh Coalmine (Maurice: Egy walesi szénbánya románca, 1905) címü regényét emlegetik. A New Companion, i. m., 418.

${ }^{19}$ A novellistaként elhíresült Caradoc Evans egyébként több regényt is megjelentetett az 1930-as és 1940es években, köztük talán az álszenteskedés ellen csatát indító Nothing to Pay (Akiknek nem kell fizetniük, 1930) művészileg a legsikeresebb. Uo., 228.
} 
és képmutató erkölcsét, valamint iszonyatos elmaradottságát, a korábban - és azóta is - sokszor idealizált gwerin közösség mítoszát teszi céltáblájává. ${ }^{20}$

A második, jórészt pályájukat az 1920-as és 1930-as években kezdő írókat magába foglaló csoportot Knight számára az iparosodott délnek az előbbieknél jóval realisztikusabb ábrázolása határozza meg, amely általában többé-kevésbé nyíltan angolellenes politikai beállítottsággal társul. Ide tartoznak olyan kiemelkedő szerzők, mint például a jellemzően D. H. Lawrence-szel barátságot ápoló, ${ }^{21}$ egyébként irodalmi karrierjét Angliában befutó Rhys Davies (1901-1978), ${ }^{22}$ a gyakran csak „három Jones”-ként emlegetett Jack Jones (1884-1970), ${ }^{23}$ Gwyn Jones (1907-1999) ${ }^{24}$ és Lewis Jones (1897-1939), ${ }^{25}$ illetve Gwyn Thomas (1913-1981) ${ }^{26}$ Hozzájuk képest értékeli Knight egyértelmü viszszalépésként a II. világháború előtti walesi irodalomnak talán egyetlen - az angol kritika és közönség által is ünnepelt, egyébként gyakran fárasztóan - melodramatikus regényét, Richard Llewellyn (1906-1983) How Green Was My Valley-jétt ${ }^{27}$ (1939). ${ }^{28}$ A mü vitathatatlanul nagy hatása jórészt annak köszönhetö, hogy teljes egészében kiszolgálja a kor angol-amerikai közönségízlését: az iparosítás által fokozatosan tönkretett dél-walesi bányavidék egykori természeti szépségét, a már felbomlott faluközösség

\footnotetext{
${ }^{20}$ KNight, A Hundred Years, i. m., 10-50.

${ }^{21}$ Jeff Wallace, Lawrentianisms: Rhys Davies and D. H. Lawrence = Rhys Davies: Decoding the Hare, ed. Meic Stephens, Cardiff, University of Wales Press, 2001, 175-191.

${ }^{22}$ Rhys Davies azon kevés walesi szerző egyike, akik a század első felében teljes egészében irodalmi munkásságukból tartották fenn magukat, így több tucatnyi regénye - legismertebb az 1944-es The Black Venus (A fekete Vénusz) - és számos novelláskötete jelent meg az 1930-as évektől az 1970-es évek elejéig. Ez utóbbiakban változatos témákat fest meg mesteri szintre fejlesztett, elsősorban Csehov elbeszéléseiből ellesett objektivitásával, humorral, az apró részletek és a drámai szituációk iránti remek érzékkel. Ugyanakkor Davies egész életében diszkréten kezelt, az írásaiban nyíltan soha meg nem jelenő homoszexuális beállítottsága a gender tanulmányok kedvelt terepévé teszi írásait. Katie Gramich, The Masquarade of Gender in the Stories of Rhys Davies = Rhys Davies, i. m., 205-215; Meic STEPHens, Introduction = Rhys Davies, i. m., 3.

${ }^{23}$ Munkáspárti elkötelezettségü szerzö, aki tucatnyi regényében, így a Black Parade-ban (Fekete parádé, 1935) és a Rhondda Roundabout-ban (Rhonddai kerülőút, 1934) rendkívüli érzékenységgel jeleníti meg a bányavidékek munkásainak sanyarú sorsát. A New Companion, i. m., 384.

${ }^{24}$ Elismert irodalomkutató, egyetemi oktató, szerkesztő, a The Mabinogion 1948-as, kritikailag is meszszemenően elismert fordításának egyik szerzője. Emellett több regény és novelláskötet írója, amelyek közül a Walesben megélt gazdasági világválság ábrázolása rokonítja Jack Jones-szal az 1936-os Times Like These (Ilyen időkben) címü müvében. Uo., 380.

${ }^{25}$ A fiatalon elhunyt baloldali aktivista két ma is autentikus benyomást keltő és magával ragadó, a délwalesi iparvidéket megörökítő regényével vonult be az irodalomtörténetbe: Cwmardy (1937) és We Live (Élünk, 1939). Uo., 393.

${ }^{26}$ Kilenc regénye Glamorgan bányavidékeinek életét örökíti meg humorral elegyedő mély együttérzéssel. Egyik legsikeresebb müve az 1831-es methyri munkásfelkelés történetét feldolgozó All Things Betray Thee (Minden elárula téged, 1949). Uo., 716. Knight, A Hundred Years, i. m., 51-93.

${ }^{27}$ Richard Llewellyn, How Green Was My Valley, London, New English Library, Hodder and Stoughton, 1984. - A regény magyar fordítása: Hová lettél, drága völgyünk?, I-II, ford. DéRY Tibor, Bp., Kozmosz, 1987.

${ }^{28}$ KNIGHT, A Hundred Years, i. m., 113-118. Llewellyn mintegy kéttucatnyi további regénye - köztük néhány közönségsiker, sok futószalagon készült szórakoztató irodalom - semmilyen tekintetben nem említhetőek egy lapon e regénnyel. A New Companion, i. m., 453.
} 
valamikori spirituális és erkölcsi egységét idézi fel mélységes nosztalgiával és helyezi idilli megvilágításba. Jelzésértékủ, hogy a II. világháború idején (1941) a későbbi évtizedek során számos angliai kiadásban megjelent regény többszörös Oscar-díjas film alapjául is szolgált. ${ }^{29} \mathrm{~S}$ végül, mintegy az angol nyelvű walesi irodalom magára találásának jegyében tárgyalja Knight a következő generációk írásait, így többek között Dylan Thomas (1914-1953) alakját, valamint a II. világháború utáni angol nyelvü walesi irodalom legmonumentálisabb írójaként, joyce-i kvalitású alakjaként tisztelt Emyr Humphreys (1919-) és az angolszász világban irodalomkritikusként széleskörüen elismert Raymond Williams (1921-1988) szépprózaíró munkásságát. ${ }^{30} \mathrm{E}$ csoport meghatározó jegye az a tudatos, az angol közönségízléstől való elszakadás jegyében megfogalmazott törekvés, hogy a „locus, a nyelv, a kultúrtörténet és a mítosz” segítségével összhangba hozza az angol kulturális hatás alatt álló és a Cymraeg Wales hagyományait. ${ }^{31}$

$\mathrm{Az}$ angol nyelvű walesi irodalom fogalmából adódó tematikai közösség mellett azonban nem csak ez utóbbi csoportban figyelhetőek meg olyan tipikus posztkoloniális attitüdök és gesztusok, mint például a nyelv problémájának középpontba állítása. Wales irodalmában az angol nyelv gyakran kényszerü választása ugyanis nem jelenti a kérdés egyszer és mindenkorra való rendezését, már csak a nyelvhasználatnak a koloniális kontextusban gyökerező politikai jelentőségéből adódóan sem. Egyrészt annak érzékeltetése, hogy az angol nyelven írt művek szereplői a regényvilágban valójában walesi nyelven, vagy legalábbis walesi dialektusban kommunikálnak egymással, kezdettől fogva megoldandó stilisztikai feladatként állt a szerzők elött.

Caradoc Evans My People címü elbeszélés-sorozatában mintegy megteremti azt a kitekert szórendü, helyenként walesi szavakat (kódváltás) is használó stilizált hibrid walesi-angol nyelvet, ${ }^{32}$ amely egy ideig irodalmi normává, majd sokszor paródia tárgyává vált. Ez az elidegenített angolság megjelenik a narrációban is, de még inkább a szereplők dialógusaiban: „Rachel, Rachel, wake you up. There’s lazy you are". ${ }^{33}$ A fordításban nem igazán visszaadható, valójában helytelen angol nyelvtani szerkezet - a normális körülmények között az egzisztenciális mondatokban használt úgynevezett üres alany, az állítmányként használt létige és az ezt teljesen szabálytalanul követö melléknév - a walesi nyelv grammatikai normáinak leképezése az angolban. Llewellyn 1939-es regénye rendszeresen alkalmazza ezt a szerkezetet az egyes szám első személyü, szóbeli történetmondást imitáló elbeszélésben: „There is

\footnotetext{
${ }^{29}$ How Green Was My Valley (Hová lettél, drága völgyünk?), rendező John Ford, föszereplő Walter Pidgeon, Maureen O'Hara, Twentieth Century Fox, 1941.

${ }^{30}$ Knight, A Hundred Years, i. m., 119-165.

${ }^{31}$ Uo., 120.

${ }^{32}$ Bohata, i. m., 106-107.

${ }^{33}$ Caradoc Evans, My People: Stories of the Peasantry of West Wales (1915), London, Andrew Melrose, évsz. nélk., 15. = Internet Archive, https://archive.org/details/mypeoplestories00evaniala (Letöltés ideje: 2016. július 3.) „Rachel, Rachel, kelj már fel. Lásd no, mily lusta vagy.” (Amennyiben külön nem jelzem a fordítót, akkor a fordítások minden esetben a sajátjaim. - R. A.)
} 
strange how things come back [...]."34 Llewellyn nyelvhasználata - és ezen keresztül inkább nosztalgikus, melodramatikus ábrázolásmódja - válik paródia tárgyává például Christopher Meredith (1955-) Shifts (Váltómüszak, 1988) című regényében. Meredith Llewellynéhez hasonló témát dolgoz fel, ámde fogcsikorgató realizmussal: a dél-walesi iparvidéknek a gazdasági válság okozta kilátástalan helyzetét mutatja be az 1980-as években. Nem csak arról van szó, hogy az ő kohómunkásai valóban Blaneau Gwent helyi tájszólásával beszélnek: ${ }^{35}$ Meredith Llewellyn tudatos kifigurázásával az 1939-es regény melodramatikus csúcspontjának, a bányarobbanásnak és a mentésben résztvevő vak (!) bokszolónak, Dai Bandónak a felidézésével, valamint a regény sematikus érzelemvilágának paródiájával - az ő stílusa ellenében definiálja önmagát:

Up comes Donald Crisp and Dai Bando on a tandem [...]. 'Look you boy bach', says blind Dai. 'There's been an explosion up at the pit. Hurry you along now begorrah. [...] They pedal and reach the scene. Young women in shawls wring their hands. Old women in shawls wail and gnash their gums. ${ }^{36}$

A szórendcsere mellett komikus színezetet ölt a kódváltás is: a valóban walesi és Evansnál, Llewellynnél is megjelenő bach (kicsi) mellé „tévedésből”, az irodalmi walesi dialektus műviségét parodizálva odakerül az ír begorrah is.

A nyelv kérdése emellett a kezdeti időszaktól tematikus elemként is problematizálódik. Így például az egyébként angol Margiad Evans szintén vidéki környezetben játszódó Country Dance című regényének főhősnőjében éppen nemzeti identitása okán dúl belső konfliktus, amely elkerülhetetlenül nyelvi aspektusokat is hordoz. ${ }^{37}$ Nevezetesen, az angol apától és walesi anyától születetett, a két ország határvidékén élő Ann Goodman - kissé hasonlatosan az amerikai „tragikus félvér” kliséjéhez - képtelen eldönteni, hogy melyik nemzethez is tartozik: leginkább mindig a másikhoz. E belső tépelődés ölt testet két udvarlója közötti ingadozásában, akik közül az egyik egy Gabriel nevü angol pásztor, a másik pedig egy sok tekintetben Emily Brontë Heathcliffére emlékezteto" ${ }^{38}$ walesi gazda, Evan ap Evans. A konfliktus tragikus véget ér: a lányt meggyilkolják, de sosem derül ki, hogy melyik féltékeny férfi volt a tettes.

\footnotetext{
${ }^{34}$ Llewellyn, How Green, i. m., 17. „Furcsa dolog, mi minden jut az ember eszébe [...].” Llewellyn, Hová lettél, i. m., I, 21.

${ }^{35}$ Dylan Moore, Greatest Welsh Novel \#3: Shifts by Christopher Meredith, Wales Arts Review, 2014. január 30., http://www.walesartsreview.org/greatest-welsh-novel-3-shifts-by-christopher-meredith/ (Letöltés ideje: 2016. július 3.)

${ }^{36}$ Christopher Meredith, Shifts, Bridgend, Seren, Poetry Wales Press, 1997, 165. „No lám, megérkezik Donald Crisp és Dai Bando egy tandemen. [...]. - Nézd no, kisfiam - mondja a vak Dai. - Robbanás volt a tárnában. Siess most velünk, istenemre. [...] Pedáloznak és a színhelyre érnek. Nagykendős fiatalasszonyok - állnak és kezüket tördelik. Nagykendős öregasszonyok - állnak, jajveszékelnek, és fogatlan ínyüket csikorgatják."

${ }^{37}$ Vö. BонатА, i. m., 119-121.

${ }^{38}$ KNIGHT, A Hundred Years, i. m., 48.
} 
Részben a nyelvi problémából születhetett már a regény izgalmas elbeszéléstechnikai megoldása is: az angol Evansnak magyarázatot kellett adnia arra, hogy a walesi föszereplőnő naplóformájú személyes vallomása mégis miért angolul íródott, ezért hamar kiderül, hogy Ann angol udvarlója számára írja naplóját, amikor hosszabb időre el kell válniuk egymástól. A magyarázat rávilágít az első személyü elbeszélő megbízhatatlanságára, hiszen ironikus távolságot iktat be a szöveg és - folyton képzelt olvasója elvárásait és érzelmeit szemmel tartó - fiktív szerzője közé. Ezzel gyakorlatilag modellálja a gyarmati szubjektum és az író, illetve a női író megfelelési kényszerét a beszélhető diskurzusokat meghatározó gyarmatosító és patriarchális diskurzus irányában. Ann érzelmeinek változását, identitása átértékelését azonban éppen a walesi nyelvhez füződő viszonyában követheti nyomon az olvasó. A lány szinte legelőször azt tudatja walesi udvarlójáról, hogy mindig anyanyelvén szól hozzá, amit Ann először értetlenkedve és elutasítással fogad: úgy tesz, mintha nem is hallaná. ${ }^{39}$ Hamarosan azonban már hetykén saját nyelvén válaszol az incselkedve udvarló férfinak. ${ }^{40} \mathrm{~S}$ minden alkalommal, amikor beszélgetéseiket idézi, mintegy védekezve, vagy éppen egyetlen várható olvasójának érzéseit szem előtt tartva, gyorsan hozzá is tesz egy angol kedvese után vágyakozó megjegyzést: „Why does he always speak to me in Welsh? I wish Gabriel would come!"41 Amikor kedvese valóban megérkezik, éppen a közös nyelv, az Evanst és Annt összekapcsoló walesiség köteléke ébreszti fel a férfi féltékenységét: „Who is that calling you dear names in Welsh, so friendly?" 42 A veszekedés hatására Ann önnön walesi identitásának és anyanyelvének a teljes elutasításába menekül. Evans érzelmeinek egyik legkézzelfoghatóbb jele viszont az, hogy a lány választott identitásának elfogadásául hajlandó angolul beszélni: „Come, Ann, look up. [...] I'm not speaking in Welsh though indeed it is on the end of my tongue, cariad." ${ }^{33}$ Persze mégiscsak belopja magát a mondatba a walesi kedveskedő megszólítás (cariad), s így a kijelentés retorikája és performativitása épp ellentétes egymással.

Ann Goodman történeténél jóval nyíltabb politikai állásfoglalásként is megjelenik a walesi irodalomban a nyelvhasználat, illetve az oktatási rendszer erőszakos angolosító hatásának kérdése. Így például az egyébként sok tekintetben a birodalmi politikát kiszolgáló Llewellyn-regényben a főszereplő első iskolai tapasztalatai azt az oktatási szituációt tematizálják, amely a Blue Books létrehozója és következménye is egyben: a tanár (tankönyv) és diák közötti nyelvi ellentétet, az erőszakos angolosítást, amely a walesi nyelv használatának tiltásában - testi fenyítéssel való szankcionálásában - mutatkozik meg. A gyermek Huw egyik legfontosabb erkölcsi győzelme az angolpárti iskolamester, Jonas elleni kiállása anyanyelvének, walesiségének védelmében. The Blue Book annak a 2000-ben Owen Sheers (1974-) tollából megjelent verseskötetnek a címe is, ${ }^{44}$ amelyet

\footnotetext{
${ }^{39}$ Margiad Evans, Country Dance (1932), Cardigan, Parthian, 2006, 18.

${ }^{40}$ Uo., 19.

${ }^{41}$ Uo., 18. „Miért beszél hozzám mindig walesiül? Bárcsak eljönne Gabriel!”

${ }^{42}$ Uo., 23. „Ki az a férfi, aki walesiül becézget téged s ilyen barátságos veled?”

${ }^{43}$ Uo., 72. „No, Ann, nézz fel rám. [...] Nem walesiül mondom, pedig itt van a nyelvem hegyén, kedvesem.”

${ }^{44}$ Owen Sheers, The Blue Book, Bridgend, Seren, Poetry Wales Press, 2000.
} 
Walesben jelöltek „Az év könyve” díjra. A toposz pedig, mely szerint az iskolamester a hódító angolok ideológiájának hordozója, még a kortárs populáris kultúra olyan könynyed alkotásában is felfedezhető, mint a The Englishman Who Went Up a Hill But Came Down a Mountain címü filmben. ${ }^{45} \mathrm{Az}$ I. világháború idejének idilli gwerin közösségét megfestő és kedves humorral felmagasztaló filmvígjátékban egyedül a feltehetően angol érzelmü tanító, Davies the School tanúsít hazafiatlan magatartást: az egész falu ellen arra fogad, hogy a walesiek nemzeti büszkeségét megtestesítő magaslat nem hegy, hanem domb, majd pedig egyedül ő nem vesz részt az összefogásban, amellyel a „dombot" egy földhányással heggyé magasítják.

Jellegzetes posztkoloniális jegy a gyarmatosító angolok történelemírásában kanonizált múlt újraírásának igénye, amely viszont elválaszthatatlan a kísérletező - modernista és posztmodern - írásmódhoz, illetve a walesi mitikus hagyományhoz való viszonynak a témájától, s egyúttal a kortárs walesi irodalom egyik legizgalmasabb irodalmi „programjának" is szülője. Ami az előbbit illeti: Knight áttekintője a gyarmatosító románcos megközelítés után érthetően Wales realista irodalmi portréjának megrajzolását helyezi elötérbe. Ez azonban nem jelenti azt, hogy az angolként felfogott s ezért elutasított modernizmus és a walesi irodalom két külön légtérben léteztek volna - legalábbis Emyr Humphreys II. világháború után induló munkásságáig, akinek műveit Knight visszavisszatérően Virginia Woolf és James Joyce írásaihoz hasonlítva tárgyalja. Hogy közel sincs ekkora megkésettségről szó, azt nem csupán Wynn Thomas véleménye jelzi, aki Dylan Thomas és jónéhány walesi kortársa müveiben a müvésszé formálódás kimondottan modernista tematikáját követi nyomon. ${ }^{46}$ Például Dylan Thomas elbeszéléskötete, a Portrait of the Artist as a Young Dog (1940) ${ }^{47}$ nyilvánvalóan ironikus viszonyt tükröz már címében is James Joyce A Portrait of the Artist as a Young Man (1916) ${ }^{48}$ című modernista művészregényéhez, miközben szerkezetében és tematikájában közeli rokonságot mutat a Dubliners (1914) novellagyüjteményével. ${ }^{49} \mathrm{Ez}$ az ironikus, ugyanakkor mégis csak az angol modernizmus újításaiból építkező megközelítés a kortárs walesi irodalomban is megfigyelhető. Jó példája az Alice Thomas Ellis írói álnéven alkotó Ann Margaret Lindholm (1932-2005) The Sin Eater (A bünnyelö, 1977) címü regénye, amely gyakorlatilag Virginia Woolf Between the Acts $(1941)^{50}$ címü müvének újraírása - kortárs walesi kontextusba helyezve. Ellis ugyanúgy egy nap és az ahhoz

\footnotetext{
${ }^{45} \mathrm{Az}$ angol, aki dombra ment fel és hegyröl jött le, rendezte Christopher MONGER, föszereplő Hugh Grant, Tara Fitzgerald, Miramax, 1995.

${ }^{46}$ Wynn Thomas, Corresponding, i. m., 75-110.

${ }^{47}$ Dylan Thomas, Portrait of the Artist as a Young Dog, London, Dent, 1956. Magyarul: Az író arcképe kölyökkutya korából, ford. Gergely Ágnes, Bp., Európa, 2008.

${ }^{48}$ James Joyce, A Portrait of the Artist as a Young Man, Harmondsworth, Penguin, 1966. Magyarul: Ifjúkori önarckép, ford. SzовоткA Tibor, Bp., Cartaphilus, 2012.

${ }^{49}$ James Joyce, Dubliners, Harmondsworth, Penguin, 1996. Magyarul: Dublini emberek, ford. PAPp Zoltán, Bp., Orpheusz, 2000.

${ }^{50}$ Virginia Woolf, Between the Acts, Harmondsworth, Penguin, 1976. Magyarul: Felvonások között, ford. TANDoRi Dezső, Bp., Európa, 2005.
} 
kapcsolódó családi összejövetel történetét mondja el, s bár a woolfi színházi előadás helyét egy amatőr krikettmérkőzés veszi át, az eseményeket „ördögi, soha nem pislogó sárga szemekkel" ${ }^{51}$ végigkövetö, Virginia Woolf néven aposztrofált birka már önmagában is jelzés értékủ akár a modell, akár a keserüen ironikus attitüd tekintetében.

Ugyancsak a kísérletező írásmód - és ezzel együtt a női írók, az angol nyelvü walesi irodalom megjelenésével szinte egy időben megtalált önálló női hangvétel - korai megjelenésére utalnak a tragikus fiatalsággal elhunyt Dorothy Edwards (1902-1934) müvei. A már Arnold Bennett által is Woolffal és Vita Sackville-Westtel együtt emlegetett, ${ }^{52}$ a Garnett-családdal és Bloomsbury-vel is kapcsolatban álló szerző Winter Sonata (Téli szonáta, 1928) ${ }^{53}$ címü regénye témájában és hangvételében is Csehov borongós elbeszéléseit idézi, mintha csak Woolf Modern Fictionben meghirdetett programját megvalósítandó venne leckéket a pszichológiai realizmus terén az orosz klasszikustól. ${ }^{54}$ A szimbolista ihletésü modernizmusnak Schopenhauer nyomán a zenét a legmagasabb rendü müvészetnek tekintő esztétikája köszön vissza a regény címében, amely egyúttal a mủ szerkezetére is utal: négy fejezetből, azaz a szonáta mintájára négy tételből áll. Mindez összhangban áll a modernista művészregénnyel rokonítható, vagy éppen annak kritikájaként is felfogható tematikával: a regény egy meg nem nevezett, de talán walesi sztereotípiaként örökké esős és kilátástalan kisváros kicsiny entellektüel körének leginkább méla unalomban eltöltött néhány hónapját követi nyomon, melybe csupán londoni barátjuk látogatása és egy csodálatos énektehetséggel megáldott, ámde szegény helyi lánnyal folytatott kalandja hoz tünő változatosságot. Dorothy Edwards, Margiad Evans és Alice Thomas Ellis csak néhány példa arra a több tucatnyi szerzőre, akiknek müveiből a walesi női irodalom kísérletező írásmódon, feminizmuson és a hibrid walesi kulturális identitás elfogadásán átívelő évszázados története rajzolódik ki - mindkét nyelven. ${ }^{55}$

Az 1920-as, 30-as évek kísérletező szellemének folytatásaként születnek a hatvanas évek óta sorra olyan izgalmas regényszövegek, amelyek a közelebbi és/vagy távolabbi történelmi múlt újraírását célozzák meg, sokszor a modernizmus elbeszéléstechnikai újításainak alkalmazásával, vagy éppen a posztmodern historiografikus metafikcióval rokonítható módon. Így például Humphreys Outside the House of Baal (Baal templomán kívül, 1965) címü regénye a két előrehaladott korú föszereplö, J. T. Miles metodista lelkész és sógornője, Kate Bannister emlékeinek foszlányaiból rajzolja ki az aszszony széthulló népes családjának, és az ő sorsukon keresztül gyakorlatilag a 20. századi Walesnek a történetét: mindezt a modernista térpoétikai fordulat (spatial turn) jegyé-

\footnotetext{
${ }^{51}$ „her yellow devil's eyes unblinking." Alice Thomas Ellis, The Sin Eater (1977), Harmondsworth, Penguin, 1986, 146.

${ }^{52}$ Katie Gramich, Twentith-Century Women's Writing in Wales: Land, Gender, Belonging, Cardiff, University of Wales Press, 2007, 56.

${ }^{53}$ Dorothy Edwards, Winter Sonata, Aberystwyth, Honno, 2011.

${ }^{54}$ Virginia Woolf, Modern Fiction = The Essays of Virginia Woolf, Volume 4: 1925 to 1928, ed. Andrew McNeille, London, The Hogarth Press, 1984, 162-163.

${ }^{55}$ Gramich, Twentith-Century Women's Writing, i. m., 183.
} 
ben, a montázs-technika eljárását is mozgósítva.$^{56} \mathrm{~A}$ földbirtokos család és szimbolikus nevü otthonuk, a közismert T. Gwyn Jones-verset (1926), valamint a római hódítás elől önpusztításba menekülő gall törzset egyaránt felidéző Argoed, ${ }^{57}$ egy tovatünő világ jelképeivé válnak a regényben, miközben a századelö politikai és morális viharaiban vergődő hősei egyre kevésbé tudnak lépést tartani az őket körülvevő modern világgal. A család tagjai minden politikai vihart személyes tapasztalatként élnek meg, kezdve a két világháború alatti pacifizmus kérdésében való állásfoglalás problémájától egészen a bányászsztrájkok alatti erkölcsileg elfogadható magatartásig. A múlt hosszú árnyéka a fiatalabb írónemzedékre is hasonlóképpen rávetül: Meredith korábban említett Shifts címü regényének két gyermekkori barát főszereplője, a húszas éveik végén járó Jack és Keith, nemcsak a bezárás előtt álló vasmüben - és így Keith feleségének ágyában váltják egymást a müszakban, hanem szinte két külön idősíkban is élnek ${ }^{58}$ Míg Jack a jelen sodródó, céltalan és végtelenül cinikus gyermeke, Keith a múlt amatőr búváraként minden szabadidejében a kisváros helytörténetét, a helyi ipar megalapításának körülményeit próbálja felderíteni. E történet a regény jelenének eseményeivel párhuzamosan íródik újra egy Keith által tartandó előadás erejéig.

Legalább ennyire központi szerepet játszik a múlt újraírása Meredith Sidereal Time (Csillagászati idő, 1998) címü, ${ }^{59}$ a tudatfolyam-regény technikáit széleskörüen alkalmazó és a modernizmussal intertextusain keresztül is állandó dialógust folytató művében is. A regény két központi alakja - Sarah, a harmincas évei közepén járó gimnáziumi tanárnő, és egyik diákja, a kamasz Steve - más-más módon kerülnek egyfajta vákuumba. Sarah a tanári pálya gépies taposómalmában rója köreit, állandó rohanása ellenére is kilátástalanul egy helyben topog. Az iskolából már fél lábbal kilógó Steve nem is tetteti, hogy a semmiféle perspektívával nem kecsegtető walesi létben valamilyen cél felé tartana - napjait üres lődörgéssel tölti. Az egyébként rendkívül intelligens tizenéves egyetlen kitörési pontja egy gyakorlatilag a fantáziavilágában „írt”, Kopernikuszról szóló „történelmi regény”, amelynek „fejezetei” váltakozva jelennek meg a kortárs környezetben játszódó narratívával.

A posztkoloniális irodalom és a posztmodern találkozási pontján létrejött mágikus realista írásmódból jól ismert eljárás a történelem (újra)írásának mitikus narratívákkal történő elegyítése, amelyhez hasonló, prominensen walesi mitikus narratívák „visszavételének” kísérletével párosuló törekvések az angol nyelvű walesi irodalomban is megfigyelhetőek. A walesi kelta néphagyományban az angolszász hódítás (5. század) idején keletkezett, és a Mabinogion (két 14-15. századi walesi nyelvü kézirat) tizenegy történetében fennmaradt narratívák legismertebb mitikus hőse - a középkori és modern magaskultúrában, majd a 20. századi populáris kultúrában is impozáns karriert

\footnotetext{
${ }^{56}$ Linden Peach, The Fiction of Emyr Humphreys, Cardiff, University of Wales Press, 2011, 131.

${ }^{57}$ Emyr Humphreys, Outside the House of Baal, Bridgend, Seren, Poetry Wales Press, 1996, 399.

${ }^{58}$ Vö. Воната, i. m., 124-125.

${ }^{59}$ Christopher Meredith, Sidereal Time, Bridgend, Seren, Poetry Wales Press, 1998.
} 
befutó - Artúr király. Már a 13. században és éppen Wales meghódításához kötődően jól dokumentált azonban a hatalmas népszerüségnek örvendő Artúr-alak angol birodalmi érdekeket szolgáló politikai célú felhasználása. İgy a Walest meghódító I. Edwardot „Artúr király koronájával” ékesítették, a későbbiekben pedig az uralkodó, hatalmát legitimálandó, többször pózolt Artúr szerepében, ahogy az egyébként valóban walesi eredetű, ám Wales önállóságát jogilag is megszüntető (1536) Tudor-ház is Artúrtól származtatta magát. A történeti Artúr valószínüsíthetően idegen - elromanizálódott brit - eredete és a hódító angolok kultúrájával való ikonikus összefonódása magyarázhatja az angol nyelvű walesi irodalomban egyrészt az Artúr-alak revízióját, másrészt a Mabinogion egyéb, erősebb walesi kötődésű narratíváinak és szereplőinek (Bendigeidfran vagy Bran és húga, Branwen, a pogány Grál, Rhiannon, Blodeuwedd, Pryderi stb.) elötérbe kerülését.

A walesi történelmet és/vagy mitikus narratívákat kísérletező jelleggel újraíró szövegek sorát kézenfekvő lenne - a tanulmány elején már említett - John Cowper Powys három nagyregényével, a Grál-legendára épülő A Glastonbury Romance-szal, ${ }^{60}$ a walesi függetlenségi harc ikonikus alakját középpontba állító és a Bran-mítoszt feldolgozó Owen Glendowerrel, illetve az Artúrt és Merlint (Myrddin Wyllt) regényalakként felvonultató, 499-ben játszódó Porius-szal nyitni. Ezeket azonban a walesi kritika rendkívül nehezen fogadja be - talán azért, mert kétségtelenül közös jegyeket mutatnak a „románcos korszak” Walest kulturálisan gyarmatosító irodalmával. E románcosság mögött azonban sok tekintetben az utóbbi évek angol nyelvü walesi irodalmával rokonítható tendenciák is rejtőznek, ami például a szövegeket Raymond Williams befejezetlen Black Mountains-trilógiájának második kötetével (1990) összeolvasva válik különösen szembeötlővé. A kortárs keretbe foglalt novellafüzér elbeszélései nagyjából ugyanezen időszak történelmi eseményeit veszik sorra - a római hódítástól (i. sz. 42) az Owain Glyn Dîrr-féle (Owen Glendower) lázadás leveréséig és a protestantizmus előfutárainak megjelenéséig (1415).

A kötet címadó darabja, a The Eggs of the Eagle (Sastojások, 1990) ${ }^{61}$ egyszerre eleveníti fel a gyakran prófétai státusszal felruházott bárd alakját, a történelem értelmezéseként és egyúttal a jövő enigmatikus előképeként magyarázott mitikus látomást - és sejtet ambivalens, iróniával füszerezett viszonyt mindkettőhöz. A római légiók kivonulása (5. század eleje) után játszódó rövidke történet föszereplője Mabon, a nagy tiszteletnek örvendő világtalan próféta, egy elpusztuló és három tojását hátrahagyó sasról szóló mitikus vízió egyetlen igazi látója. A tojásokból sorrendben vérfolyam, egy életképtelen, szájában halat tartó fehér pelyhes sasfióka, és fojtogató sárga köd vagy füst támad. A Mabont körülvevő bölcsek a történet - mint prófécia - különböző értelmezéseit adják: abban ugyan megegyeznek, hogy a sas a Római Birodalom tovatünt hatalmát jelzi, ám

\footnotetext{
${ }^{60}$ John Cowper Powys, A Glastonbury Romance (1932), London, Macdonald, 1955.

${ }^{61}$ Raymond Williams, People of the Black Mountains, volume 2.: The Eggs of the Eagle, London, Paladin, 1992, 66-72.
} 
mindegyikük számára másik tojás jelzi a jövőt, és ehhez a jövőhöz is eltérően viszonyulnak. A vérfolyamban egyikük a rómaiak kivonulása utáni testvérviszály allegóriáját látja, míg másikukat arra emlékezteti, hogy a római hódítás előtt is ölték egymást a britek, tehát nem lehet egy idilli, sosem volt múltat kreálni. A szájában halat tartó, pelyhes sasfióka utalás lehet a Halászkirály legendájára (vagy inkább a Halászkirályok - a szereplők számára - nagyon is valós történelmi alakjaira), de az új, keresztény hitre is, mely szintén Róma öröksége, és eltántorítja a keltákat saját vallásuktól. A sárga köd az erős központi hatalom, a hódító távozta után támadó bizonytalanság és kétely allegóriája az egyik szereplő számára - az olvasónak pedig talán finom utalás T. S. Eliot „mitikus módszerére" a J. Alfred Prufrock szerelmes énekének egyik központi motívumán keresztül. A vitát a szereplők Mabon autoritására támaszkodva szeretnék lezárni, aki azonban - akárcsak Marlow hallgatósága A sötétség mélyénben - mélységes ironikus távolságtartást sugallva, egy ideje már elszunnyadt.

Mivel az elbeszélés a kötet címadó szövege, nehéz ellenállni a metanarratívaként olvasás kísértésének. Egyrészt párhuzam fedezhető fel a mitikus látomás, mint történelem-értelmezés és prófécia elmondása, valamint a kötet azon gesztusa között, hogy a walesi történelem sorsfordító eseményeit mitikus elemek és szereplők (például a Halászkirály, Artorius avagy Artúr a soron következő történetben) bevonásával, ám ugyanakkor hétköznapi embereket középpontba állítva mondja el, szubjektív élményként. Másrészt az elbeszélés a történetként felfogott történelem többértelműségére, végső igazságának megkérdőjelezhetőségére hívja fel a figyelmet, miközben egyszerre támaszkodik a modernista mitizálás hagyományára és fordul iróniával a végső értelmező paradigmaként felfogott mítosz gondolata felé. Mégis, a látomás nagyon is hatékony értelmező keretét adja a kötet elbeszéléseiből kirajzolódó walesi történelemnek: a sas nemcsak a rómaiaknak, hanem az egymást váltó megszállóknak, birodalmaknak a trópusa is, amelyeknek örökében újra meg újra vérontás és káosz jár a hatalmi harcok kereszttüzében álló országban. Ennek következtében Wales történelmi múltjának feltárása nem lehet valamiféle mitikus narratíva által egyértelmüen körülhatárolt ősi nemzeti identitás felfedése - legfeljebb a számtalan hódítás és kulturális behatás által egymásra írt rétegek végtelen palimpszesztjéntek felfejtése. És semmiképpen sem azonos annak az Artoriusnak a történetével, aki a soron következö, In the Shadow of Artorius (Artorius árnyékában $)^{62}$ címü elbeszélésben inkább római, mint brit - hiszen nevetségessé is teszi magát hibás kelta beszédével ${ }^{63}-, \mathrm{s}$ akinek puszta léte már a kortársak számára is annyira távoli homályba vész, hogy a róla szóló történetek függvénye csupán: Artorius létezik, „if we hear of him again”. ${ }^{64}$

A posztkoloniális „visszavételek” sorába illeszkedik a Seren Books 2009-ben indított, és gyakorlatilag a modernista mitizáló hagyományt folytató kezdeményezése: a

\footnotetext{
${ }^{62}$ Uo., $73-82$.

${ }^{63}$ Uo., 79.

${ }^{64}$ Uo., 82. „ha hallunk még róla”
} 
Mabinogion történeteinek modern, kimondottan walesi újraírása. A 2013-ban teljessé vált tízkötetes sorozat darabjai felkérésre születtek, a kiadó ugyanis azzal keresett fel néhány jó nevü fiatal írót, hogy válasszanak egyet a történetek közül és adaptálják a kortárs, de legalábbis 20. századi kontextushoz - az adaptáció tényét hangsúlyozandó a releváns Mabinogion-történet szinopszisa meg is jelenik a kötetek végén. A sorozat szerzői között szerepel például a sokszor Irvine Welshhez hasonlított Niall Griffiths (1966-), Lloyd Jones (1951-), Cynan Jones (1975-), és Owen Sheers (1974-) - mindannyian a walesi „Az év könyve” díj nyertesei, Owen Sheers több alkalommal is. A sorozat alapvető stratégiáját és egyben sokszínűségét jól mutatja például Griffiths és Sheers történetválasztása, illetve az, ahogy e történeteket saját „szájuk íze” szerint alakítják. Griffiths a Mabinogion talán két legnehezebben értelmezhető és legszürreálisabb történetét dolgozta fel, két álmot, a Rhonabwy's Dream ${ }^{65}$ és The Dream of Maxen Wledig ${ }^{66}$ címü narratívákat. Az egyiket gyakorlatilag kábítószeres víziók sorává alakítja, a másikat pedig egy gengszter komikus szerelmi ábrándjának, megcsalatásának és bukásának történetévé. ${ }^{67}$ Sheers viszont White Ravens (Fehér hollók, 2009) címen Branwennek (szó szerint fehér hollót jelent), a legendás óriás Bran húgának tragikus házasságát, illetve az ezzel összefonódó walesi-ír konfliktust ${ }^{68}$ viszi újra színre a két síkon - a II. világháború idején szerelmi szálon, és a jelenben testvérviszályként - futó történetben. Azaz Griffiths, egyéb regényeihez hasonlatosan, walesi szubkultúrák végtelenül kiábrándult és szenvtelen ábrázolásának szubtextusaként használja a mitikus szövegeket. Sheers, ezzel ellentétben, az egyik leghatározottabb morális üzenettel bíró narratíva - a nemzetek közötti háborúban megölt óriás Bran testét ajánlja hídul, összekötő kapocsként az ellentétben - tanulságát ismétli meg igenlően, erkölcsi tanításként. Az ír származású nagyapa regényt záró szavaival arra biztatja walesi unokáját, a kilátástalan jelenben bátyjaitól elszakadt Rhiant (Rhiannon), hogy nagyszülei viszályából tanulva térjen vissza testvéreihez és a legendás Branhoz hasonlatosan legyen kapocs közöttük: „Go back to your brothers now. Help them. Be a bridge." ${ }^{9}$

A fenti körkép ékesen illusztrálja, hogy az angol nyelvű walesi irodalom messze nem szorítkozik a magyar köztudatban ikonikus walesi bárdok, vagy konkrétan - az image-ét tudatosan a bárdikus hagyományra építő, egyébként csak angolul beszélö, neo-romantikus - Dylan Thomas ${ }^{70}$ költői hagyományára, de még csak a költészetre sem. Ez utóbbi a hazánkban is széles körben ismert Thomas mellett olyan emblematikus alakokat vonultat fel, mint az angol modernista körökhöz kapcsolódó, az első vi-

\footnotetext{
${ }^{65}$ The Mabinogion, ford. Charlotte E. Guest, New York, Dover, 1997, 94-104. Magyarul: Rhonabwy álma = Mabinogion: walesi legendák, ford. Kácsor Loránt, Bp., General Press, 2008, 308-322.

${ }^{66}$ The Mabinogion, i. m., 52-57. Magyarul: Maxen császár álma = Mabinogion, i. m., 171-179.

${ }^{67}$ Niall Griffiths, The Dreams of Max and Ronnie, Bridgend, Seren, Poetry Wales Press, 2010.

${ }^{68}$ The Mabinogion, i. m., 16-26. Magyarul: A Mabinogi második ága = Mabinogion, i. m., 73-88.

${ }^{69}$ „Most menj vissza a bátyáidhoz. Segíts nekik. Legyél híd.” Owen SHeErs, White Ravens, Bridgend, Seren, Poetry Wales Press, 2011, 180.

${ }^{70}$ D. RÁcz István, A másik ország: az angol költészet 1945 után, Debrecen, Kossuth Egyetemi Kiadó, 2006, 23.
} 
lágháborút megörökítő 1937-es hosszú költeményéről elhíresült David Jones (18951974), vagy az egész korszakot meghatározó, mélyen nemzeti érzületű pap-költő, $R$. S. Thomas (1913-2000). Mégis, az amatör költőversenyekhez (Eisteddfod) kötődő, középkori müfaji hagyományokat továbbvivő walesi költészet szorosabb szálakkal kapcsolódik a „Cymraeg” irodalomhoz, és jelentős mértékben hozzáférhetetlen az angol nyelven olvasók számára. Szemben az utóbbi évtizedekben egyre izgalmasabb hangokkal tarkított, sokszor eredeti hangvételü, ugyanakkor a brit kísérletező hagyománnyal élénk diskurzust folytató angol nyelvü walesi prózával.

\section{Angelika ReichmanN \\ Welsh Writing in English: An Introduction}

The present article was written as a chapter of a literary historical project which aims to present an overview of English Literature to Hungarian readers. Hence its introductory nature: apart from the works of Dylan Thomas, Welsh writing in English has been hardly translated into Hungarian and is little known. After clarifying the somewhat convoluted term, the article provides a survey of the literary historical periods in Welsh writing in English since its emergence in front of the backdrop of industrialisation and aggressively imperial English language politics at the turn of the $19^{\text {th }}$ and $20^{\text {th }}$ centuries. Then it proceeds to highlight five characteristics of that literature from a postcolonial perspective. Through selective micro-analyses of largely contemporary prose works, the article focuses on such aspects of Welsh writing in English as its concern with language itself (code-switching) and with rewriting Welsh history. In relation to the latter, it discusses the early presence of experimental tendencies and women writers, and the literature's emphatic and recently "institutionalised" reassessment of the Welsh mythical heritage. 